\title{
Public Marketing: Case of Self-governing Regions' Brands in Online Environment
}

\author{
Pavel BACHMANN
}

University of Hradec Kralove, Hradec Kralove, Czech Republic; pavel.bachmann@uhk.cz

\begin{abstract}
Online environment, including brands of public institutions, is becoming a significant part of public administration. Nowadays, with a social media communication widespread, the public marketing managers representing self-governing regions are forced to work on their image and monitor and influence region's brand behavior in the online environment. Therefore, an article aims on the current state of art in the field of public brand marketing and the nature of mentions of users (citizens) about this brand. The study employed data obtained with use of Brand24.com application which automatically collect the data on region's brands behavior in the online environment. The analysis is oriented on following aspects: (1) brand's mentions in online environment, (2) number of social media views and interactions raised over the brand, and (3) the level of positive and negative sentiment related to the brand. The research sample included 13 out of 14 regions existing in the Czech Republic, for research reasons the capitol city of Prague was excluded from the sample. The findings showed that high regional differences in brand awareness, brand's social media reach as well as brand's associated text sentiment exist. Besides of this, several implications for public marketing managers are presented in the study.
\end{abstract}

Keywords: self-governing region; brand; online environment; social media; public administration; Czech Republic

JEL Classification: H30; M30

\section{Introduction}

Increased citizen's participation in online environment together with the information and communication technologies (ICT) developments have created new challenges for public marketing. Fung (2015) asserts that citizen participation mainly supports "three aspects of governance: effectiveness, legitimacy, and social justice". The emergence of omnipresent use of online communication, particularly Web 2.0 and 3.0 and social media communication meant that public institutions, including government and local governments, and their brands need to be more visible to citizens in virtual space.

\section{State of the Art in Brand Marketing Research}

In the past decade, the "branding had become an open source activity, via which anyone and everyone had a say in matters of the brand" (Fournier and Avery 2011). Remarkably, it means that brands started to live with their own life, sometimes working against the creators. Fournier and Avery (2011) commented it in this way: "When marketers created stylized content that could be spread virally, they were horrified to see these same sharing capabilities used against them. Consumers hijacked brand messages and turned them into parodies". The brand oriented research mainly focus on business administration issues as consumer vs brand generated platforms (van Noort and Willemsen 2012), brand consciousness on consumption behavior in terms of consumption motivations, purchase intention, and brand loyalty oriented on Generation $\mathrm{Y}$ and luxury fashion industry (Giovannini, $\mathrm{Xu}$, and Thomas 2015), or influence of parasocial (robotic) interactions in online social media (Yuksel and Labrecque 2016). There are also many studies related to health-related environment as branding of cigarettes its impact on smokers (Huang, Kornfield, and Emery 2016; Kim, Hopper, and Simpson 2015; Ulucanlar, Fooks, and Hatchard 2014; Farsalinos et al. 2013), use of psychotics (Corazza, Valeriani, and Bersani 2014), or food and drink consumption (Freeman et al. 2016; Holmberg et al. 
2016). In the field of public sector, and particularly public institutions, there are exist only a bit out-todate, studies related to the brand and community (Kane et al. 2009) or place branding (Anholt 2008).

Moreover, the brands are usually presented in different context, which is in the form of online comments available on websites or social media. For this reason, the sentiment of the text associated with the brand should be determined. These texts are presented as unstructured information source which is difficult to analyze and requiring time-consuming and expert focused approach (GonzálezRodríguez, Martínez-Torres, and Toral 2016). To avoid this approach, we applied a sentiment analysis tool incorporated in the software application presented later in this text.

As it was showed earlier in the text, there is unfortunately not enough up-to-date research done in the field of brand "behavior" in context of public institutions and the public sector, in general. Therefore, this study aims on identification of brand awareness of the region's brand among users (and thus likely citizens) who communicate online with the region, and at the same time, on the engagement of citizens in this brand and the sentiment of communication about the brand.

\section{Methodology}

\subsection{Methods and Metrics}

The study is based on the analysis of online environment to identify brand's presence. This kind of analysis conducted in online environment is a part of so-called Internet mediated research (Hewson 2007). For the purpose of this study a new set of metrics to measure brand presence in the online environment as well as brand's engagement by citizens and the sentiment of relevant communication was designed by the author. These metrics are mainly based on the definitions of terms outlined by social networks as Facebook, YouTube and Twitter.

Table 1. Metrics of brand's word-of mouth, interactions, and sentiment.

\begin{tabular}{|c|c|}
\hline Specific Metrics & Description of the metrics \\
\hline Mentions & $\begin{array}{l}\text { All available presences of the region's brand in online environment. The brand can be } \\
\text { mentioned as the passive presence (with not interactive linking on the brand's profile) } \\
\text { or in active presence (with an interactive link). }\end{array}$ \\
\hline $\begin{array}{l}\text { Social Media } \\
\text { Mentions }\end{array}$ & $\begin{array}{l}\text { Mentioning a brand (or person/page) on social media is the electronic way of tagging } \\
\text { someone on the social media networks, and by mentioning the brand it links to that } \\
\text { brand's social media profile. Usually, it uses active mentioning of the brand. }\end{array}$ \\
\hline $\begin{array}{l}\text { Non social media } \\
\text { mentions }\end{array}$ & $\begin{array}{l}\text { Mentioning a brand in traditional online environment, mainly websites. Usually, it } \\
\text { uses passive mentioning of the brand. }\end{array}$ \\
\hline Social media reach & $\begin{array}{l}\text { The total number of people who has seen the specific brand during a specific period } \\
\text { (last } 30 \text { days in this study) in the online environment. }\end{array}$ \\
\hline Interactions & $\begin{array}{l}\text { The metrics involves how the brand's institution talking to individuals on social } \\
\text { media (Twitter and blogs interactions are considered in this study). This interaction } \\
\text { can be both reactive (to people who have messaged your brand) and proactive (to } \\
\text { people you reach out based on one or more factors). }\end{array}$ \\
\hline Shares & $\begin{array}{l}\text { Reflects how many times the text associated with the specific brand was shared on } \\
\text { social media }\end{array}$ \\
\hline Likes & $\begin{array}{l}\text { Reflects how many likes the text associated with the specific brand received on social } \\
\text { media }\end{array}$ \\
\hline Sentiment & $\begin{array}{l}\text { This metric reflects either positive or negative sentiment of the text associated with the } \\
\text { specific brand. Texts with neutral sentiment are neglected. }\end{array}$ \\
\hline
\end{tabular}

\subsection{Collection of the Data Set and a Software Used for Data Gathering}

The data of analyzed facets were gathered during a thirty-day period from January 12, 2020 to February 11, 2020. Data were collected with use of Brand24.com application tool and after the collection processed in MS Excel for the purpose of regional comparison. Brand24.com application was used in the past with many organizations as well as start-ups. For better picture, how an organization 
can use this application, Krzysiek Radoszewski, the Marketing Lead for Central and Eastern Europe at Uber, says on this: "At Uber, we use social listening on a daily basis, which allows us to understand how our users feel about the changes we are implementing. As soon as we introduce a modification, we know which pars of it are greeted with enthusiasm, and which need more work" (Brand24.com 2020). Similarly, the success or failure of a specific regional policies, or regional administration quality can be measured with used application.

\subsection{Research Sample}

Research study focuses on analysis of online communication of self-governing regions. The Czech Republic regions are established according to the Act no. 129/2000 on Higher-level territorial selfgoverning units (Czech Republic 2018). The thirteen regions and one capital city with regional status exist. The capitol Prague was excluded from the sample due to several facts: much higher tourist attention, almost doubled GDP per capita (39,902 EUR), as well as significantly higher population $(1,272,690$ inhabitants) than majority of regions. In the sample, there are three regions exceeding with population exceeding one million citizens; at the other end, there are two regions with population lower than a half million of inhabitants: Liberec region with population of 441 thousands, and Karlovy Vary region with population of 296 thousands.

The detailed characteristics of the regions researched are summarized in Table 2.

Table 2. List of regions included in the sample. (Czech Statistical Office, 2018)

\begin{tabular}{cccc}
\hline Region's official name & Population ${ }^{1}$ & $\begin{array}{c}\text { Area } \\
\left(\mathrm{km}^{2}\right)\end{array}$ & $\begin{array}{c}\text { GDP per capita } \\
(\text { EUR) }\end{array}$ \\
\hline Středočeský kraj & $1,345,764$ & $11,014.97$ & 16,930 \\
Jihočeský kraj & 639,180 & $10,056.79$ & 14,698 \\
Kraj Vysočina & 508,664 & $6,795.56$ & 14,893 \\
Plzeňský kraj & 579,228 & $7,560.93$ & 16,737 \\
Karlovarský kraj & 296,106 & $3,314.46$ & 11,992 \\
Ústecký kraj & 820,937 & $5,334.52$ & 13,112 \\
Liberecký kraj & 440,934 & $3,162.93$ & 13,853 \\
Královéhradecký kraj & 550,848 & $4,758.54$ & 16,791 \\
Pardubický kraj & 517,243 & 4,519 & 14,738 \\
Olomoucký kraj & 633,133 & $5,266.57$ & 14,196 \\
Moravskoslezský kraj & $1,207,419$ & $5,426.83$ & 14,922 \\
Jihomoravský kraj & $1,180,477$ & $7,194.56$ & 17,098 \\
Zlínský kraj & 583,039 & $3,963.55$ & 15,498 \\
\hline
\end{tabular}

\section{Analysis and Results}

\subsection{Brand's Mentions in the Online Environment}

Brand's mentions were represented by all available mentions about the brand in the online environment. The total number of mentions recorded for all sampled regions was 2,654 . The number of mentions in the individual regions ranged from 331 mentions about Středočeský (Central Bohemian) region to 101 mentions about Liberec region. The non social mentions were represented by higher percentage out of the all mentions, the highest number of these mentions was recorded in Olomouc region (294); the lowest was recorded in Liberec region. The highest number of social media mentions was found in Středočeský (70), Ústecký (65) and Zlínský (52) region. On the other side, the lowest number of these mentions was found in Vysočina (10) and Olomouc (14) region.

More detailed data about number of mentions in individual regions are available in Table 3. 
Table 3. Brand's mentions according to official name of regions.

\begin{tabular}{|c|c|c|c|c|}
\hline \multirow{2}{*}{ Region's official name } & \multicolumn{2}{|c|}{ Mentions } & \multirow{2}{*}{$\begin{array}{l}\text { Social Media } \\
\text { Mentions }\end{array}$} & \multirow{2}{*}{$\begin{array}{c}\text { Non Social } \\
\text { Media } \\
\text { Mentions }\end{array}$} \\
\hline & Abs. & Rel. & & \\
\hline Středočeský kraj & 331 & 12.47 & 70 & 261 \\
\hline Ústecký kraj & 312 & 11.76 & 65 & 247 \\
\hline Olomoucký kraj & 308 & 11.61 & 14 & 294 \\
\hline Jihomoravský kraj & 299 & 11.27 & 43 & 256 \\
\hline Moravskoslezský kraj & 267 & 10.06 & 25 & 242 \\
\hline Zlínský kraj & 243 & 9.16 & 52 & 191 \\
\hline Karlovarský kraj & 227 & 8.55 & 46 & 181 \\
\hline Pardubický kraj & 227 & 8.55 & 31 & 196 \\
\hline Jihočeský kraj & 197 & 7.42 & 24 & 173 \\
\hline Plzeňský kraj & 172 & 6.48 & 20 & 152 \\
\hline Královéhradecký kraj & 171 & 6.44 & 19 & 152 \\
\hline Kraj Vysočina & 130 & 4.90 & 10 & 120 \\
\hline Liberecký kraj & 101 & 3.80 & 19 & 82 \\
\hline In total & 2,654 & 100.0 & 368 & 2,286 \\
\hline
\end{tabular}

\subsection{Social Media Reach and Interactions}

Overall number of social media reach in all sampled regions was 616,369 views. On the contrary to the previous results in individual regions, the social media reach can importantly differ from overall number of mentions. The highest social media reach was recorded in Liberec and Zlín regions with more than 150 thousand of users who have viewed the region's brand. On the other side, there are five regions where the social media reach is lower than 10 thousand of views: South Bohemian (Jihočeský), Plzeň, Pardubice, Olomouc and Vysočina.

The highest number of interactions was found in case of Liberec (472) and Ústí nad Labem (340) region. On the other hand, very low number of interactions existed in case Hradec Králové (Královéhradecký) (44), Plzeň (37), Vysočina (31) and Olomouc (17) region. Much higher percentage of interactions is made by likes (91.1\%) in comparison to shares $(9.9 \%)$.

More detailed data about social media reach and interaction are available in Table 4.

Table 4. Word of mouth about brands of regions.

\begin{tabular}{ccccc}
\hline Region's official name & $\begin{array}{c}\text { Social media } \\
\text { reach }\end{array}$ & Interactions & Shares & Likes \\
\hline Liberecký kraj & 157,000 & 472 & 36 & 435 \\
Zlínský kraj & 156,000 & 240 & 25 & 213 \\
Ústecký kraj & 105,000 & 340 & 36 & 285 \\
Jihomoravský kraj & 87,280 & 128 & 19 & 107 \\
Moravskoslezský kraj & 38,267 & 97 & 3 & 91 \\
Karlovarský kraj & 30,114 & 383 & 57 & 324 \\
Královéhradecký kraj & 18,036 & 44 & 0 & 44 \\
Středočeský kraj & 12,900 & 495 & 42 & 453 \\
Jihočeský kraj & 9,794 & 57 & 5 & 47 \\
Plzeňský kraj & 7,038 & 37 & 1 & 32 \\
Pardubický kraj & 3,420 & 150 & 7 & 116 \\
Olomoucký kraj & 2,213 & 17 & 0 & 17 \\
Kraj Vysočina & 2,207 & 31 & 2 & 29 \\
\hline
\end{tabular}




\begin{tabular}{rrrrr}
\hline In total & 616,369 & 1,996 & 191 & 1,740 \\
\hline
\end{tabular}

\subsection{Sentiment of Brand}

The overall sentiment of all brands in sampled regions was slightly positive and reached ratio of 1.11 , where the positive vs negative sentiment is measured. Significantly higher sentiment ratio for the brand was found in Plzeň (5.83) and Hradec Králové (Královéhradecký) (4.33) region. Negative sentiment of region's brand was recorded in five following regions: South Moravian (Jihomoravský) (0.83), Pardubice (0.65), Olomouc (0.62), Zlín (0.55), and Liberec (0.38) region.

More detailed data about social media reach and interaction are available in Table 5.

Table 5. Word of mouth about brands of regions.

\begin{tabular}{cccccc}
\hline \multirow{2}{*}{ Region's official name } & \multicolumn{2}{c}{$\begin{array}{c}\text { Positive } \\
\text { sentiment }\end{array}$} & \multicolumn{2}{c}{$\begin{array}{c}\text { Negative } \\
\text { sentiment }\end{array}$} & $\begin{array}{c}\text { Sentiment Ratio } \\
\text { (positive vs. } \\
\text { negative) }\end{array}$ \\
\cline { 2 - 5 } & Abs. & Rel. & Abs. & Rel. & 5.83 \\
\hline Plzeňský kraj & 35 & 12.28 & 6 & 2.34 & 4.33 \\
Královéhradecký kraj & 26 & 9.12 & 6 & 2.34 & 2.56 \\
Moravskoslezský kraj & 23 & 8.07 & 9 & 3.52 & 2.09 \\
Karlovarský kraj & 23 & 8.07 & 11 & 4.30 & 1.56 \\
Jihočeský kraj & 14 & 4.91 & 9 & 3.52 & 1.44 \\
Ústecký kraj & 46 & 16.14 & 32 & 12.50 & 1.17 \\
Středočeský kraj & 14 & 4.91 & 12 & 4.69 & 1.11 \\
Kraj Vysočina & 10 & 3.51 & 9 & 3.52 & 0.83 \\
Jihomoravský kraj & 20 & 7.02 & 24 & 9.38 & 0.65 \\
Pardubický kraj & 26 & 9.12 & 40 & 15.63 & 0.62 \\
Olomoucký kraj & 39 & 13.68 & 63 & 24.61 & 0.55 \\
Zlínský kraj & 17 & 5.96 & 31 & 12.11 & 0.38 \\
Liberecký kraj & 6 & 2.11 & 16 & 6.25 & 1.11 \\
In total & 285 & 100.0 & 256 & 100.0 & \\
\hline
\end{tabular}

\section{Discussion}

The findings showed some interesting insights in the understanding of brand awareness and brand sentiment in individual regions of the Czech Republic.

(1) At first, the results showed that media mentions are still more present in the environment of traditional online tools as websites of the region itself, websites inter-connected with the region, local daily and weekly news, or communication of the police stations and social media do not play a significant role in the overall mentions about the brand, yet. (2) At second, the significant differences in approach to online marketing exist in individual regions. For example, the Liberec region, which recorded the lowest number of overall online mentions at the same time received the highest social media reach. Which can mean that the marketing or public relations managers focus rather on social media activities than website oriented online communication. (3) At third, there were also found high differences in sentiment associated with the region's brand. While there are two regions with highly positive sentiment and two other with moderate positive, there are also five regions with negative sentiment. In this case, the Liberec region is interesting example, because despite of very high social media reach, the region received the most negative sentiment of the brand. Such negative connotations can be considered as a danger for current political representation of the region.

From the general perspective, an inspiration of business sector practice in the field of online reputation management, can be useful. In this comparison, the regional office governing the entire region would correspond to a large-scale business entity with high number of employees and huge 
number of customers. The research of Kantorová and Bachmann (2018) showed that such large business companies pay high attention to "strategic approach to online community management and also making their own online communities". Regional authorities should therefore integrate such approach, at least to a limited extent, into their management practice.

\section{Conclusion and Managerial Implications}

This study has brought a new knowledge in the field of region's brand awareness of the region's citizens who communicate online with the region. Also, it examined engagement of citizens by this brand and the sentiment of communication which is associated with the brand.

Moreover, the study findings reveal several implications to public marketing managers of the regions. Nowadays, the managers should be familiar with the necessity to regularly monitor the brand's awareness, reach, and sentiment because it can be done easily and with high exactness with the use of relevant software. Also, they should deal with the content analysis of citizen's comments generating highly positive or highly negative sentiment of the brand mentions in online environment. At the same time, they should be prepared to influence and modify such positive or negative content by providing a proper and in-time online communication.

\section{References}

Anholt Simon. 2008. Place branding: Is it marketing, or isn't it? Place Branding and Public Diplomacy: 4(1), 1-6. https://doi.org/10.1057/palgrave.pb.6000088.

Brand24. 2020. Brand24 - Media Monitoring Tool. Available online: https://brand24.com/ (accessed on 10 January 2020).

Corazza Ornella, Valeriani Giuseppe, Bersani Francesco Saverio et al. 2014. "Spice," "Kryptonite," "Black Mamba": An Overview of Brand Names and Marketing Strategies of Novel Psychoactive Substances on the Web. Journal of Psychoactive Drugs: 46(4), 287-294. https://doi.org/10.1080/02791072.2014.944291.

Czech Republic. 2018. Act no. 129/2000 Coll. (Law on Regions) on higher-level territorial self-governing units, Available online: https://ipfs.io/ipfs/QmXoypizjW3WknFiJnKLwHCnL72vedxjQkDDP1mXWo6uco/ wiki/Regions_of_the_Czech_Republic.html (accessed on 12 January 2018).

Czech Statistical Office. 2018. Vybrané demografické údaje podle krajů v roce 2017 (Selected demographic data according to regions in 2017). Available online: https://www.czso.cz/csu/czso/4-obyvatelstvo-prabaiz95y (accessed on 10 January 2020).

Farsalinos Konstantinos E., Romagna Giorgio, and Tsiapras Dimitris et al. 2013. Impact of flavor variability on electronic cigarette use experience: an internet survey. International Journal of Environmental Research and Public Health: 10(12), 7272-7282. https://doi.org/10.3390/ijerph10127272.

Fournier Susan, and Avery Jill. 2011. The uninvited brand. Business Horizons: 54(3), Special Issue. 193-207. https://doi.org/10.1016/j.bushor.2011.01.001.

Freeman Becky, Kelly Bridget, Vandevijvere Stefanie, and Baur Louise. 2016. Young adults: beloved by food and drink marketers and forgotten by public health? Health Promotion International: 31(4), 954-961. https://doi.org/10.1093/heapro/dav081.

Fung Archon. 2015. Putting the Public Back into Governance: The Challenges of Citizen Participation and Its Future. Public Administration Review: 75, 513-522. https://doi.org/10.1111/puar.12361.

Giovannini Sarah, Xu Yingjiao, and Thomas Jane. 2015. Luxury fashion consumption and Generation Y consumers Self, brand consciousness, and consumption motivations. Journal of fashion marketing and management: 19(1), 22-40. https://doi.org/10.1108/JFMM-08-2013-0096.

González-Rodriguez Rosario M., Martínez-Torres Rocio, and Toral Sergio. 2016. Post-visit and pre-visit tourist destination image through eWOM sentiment analysis and perceived helpfulness. International Journal of Contemporary Hospitality Management: 28(11), 2609-2627. https://doi.org/10.1108/IJCHM-02-2015-0057.

Hewson Claire. 2007. Gathering data on the Internet. Qualitative approaches and possibilities for mixed methods research. The Oxford Handbook of Internet Psychology. Oxford University Press, UK.

Holmberg Christopher, Chaplin John E., and Hillman Thomas et al. 2016. Adolescents' presentation of food in social media: An explorative study. Appetite: 99, 121-129. https://doi.org/10.1016/j.appet.2016.01.009. 
Huang Jidong, Kornfield Rachel, Emery Sherry L. 2016. 100 Million Views of Electronic Cigarette YouTube Videos and Counting: Quantification, Content Evaluation, and Engagement Levels of Videos. Journal of Medical Internet Research: 18(3), e67. https://doi.org/10.2196/jmir.4265.

Kane Gerald C., Fichman Robert G., Gallaugher John et al. 2009. Community Relations 2.0. Harvard Business Review: 87(11), 45-+.

Kantorova Katerina, and Bachmann Pavel. 2018. Social Customer Relationship Management and Organizational Characteristics. Information: 9(12), 306. https://doi.org/10.3390/info9120306.

Kim Annice E., Hopper Timothy, Simpson Sean et al. 2015. Using Twitter Data to Gain Insights into E-cigarette Marketing and Locations of Use: An Infoveillance Study. Journal of Medical Internet Research: 17(11), e251. https://doi.org/10.2196/jmir.4466.

Ulucanlar Selda, Fooks Gary J., Hatchard Jenny L. et al. 2014. Representation and Misrepresentation of Scientific Evidence in Contemporary Tobacco Regulation: A Review of Tobacco Industry Submissions to the UK Government Consultation on Standardised Packaging. Plos Medicine: 11(3). https://doi.org/10.1371/journal.pmed.1001629.

van Noort Guda, Willemsen Lotte M. 2012. Online Damage Control: The Effects of Proactive Versus Reactive Webcare Interventions in Consumer-generated and Brand-generated Platforms. Journal of interactive marketing: 26(3), 131-140. https://doi.org/10.1016/j.intmar.2011.07.001.

Yuksel Mujde, Labrecque Lauren I. 2016. "Digital buddies": parasocial interactions in social media. Journal of Research In Interactive Marketing: 10(4), 305-320. https://doi.org/10.1108/JRIM-03-2016-0023. 